This item was submitted to Loughborough's Research Repository by the author.

Items in Figshare are protected by copyright, with all rights reserved, unless otherwise indicated.

\title{
Social media advertising: Factors Influencing Consumer Ad Avoidance
}

PLEASE CITE THE PUBLISHED VERSION

https://doi.org/10.1362/147539217X14909733609398

PUBLISHER

Westburn Publishers

VERSION

AM (Accepted Manuscript)

\section{PUBLISHER STATEMENT}

This work is made available according to the conditions of the Creative Commons Attribution-NonCommercialNoDerivatives 4.0 International (CC BY-NC-ND 4.0) licence. Full details of this licence are available at: https://creativecommons.org/licenses/by-nc-nd/4.0/

\section{LICENCE}

CC BY-NC-ND 4.0

\section{REPOSITORY RECORD}

Ferreira, C., Nina Michaelidou, Caroline Moraes, and M. McGrath. 2019. "Social Media Advertising: Factors Influencing Consumer Ad Avoidance”. figshare. https://hdl.handle.net/2134/24186. 


\title{
Title
}

Social Media Advertising: Factors Influencing Consumer Ad Avoidance

\begin{abstract}
Social media has become a key field for expansion of advertising. However, despite the enthusiasm of both advertisers and technology providers, intense advertising on social media may result in companies' messages being lost amongst the 'noise'. This has led advertisers to create more daring adverts in order to stand out. However, such 'controversial' adverts may, subsequently, turn consumers off, leading consumers to avoid ads. This study examines potential factors influencing consumers' decisions to avoid controversial ads on social media. Using data on social media usage from 273 consumers, a conceptual model of social media ad avoidance antecedents was tested via structural equation modelling. The results show that perceptions of adverts as controversial result in ad avoidance, but this effect is moderated by individual factors, such as ethical judgement. These results reveal noteworthy insights that have significant theoretical and practical implications for researchers in the area, and social media marketers alike.
\end{abstract}

\section{Keywords}

Social media advertising; advertising avoidance; controversial adverts; structural equation modelling 


\section{SOCIAL MEDIA ADVERTISING:}

\section{FACTORS INFLUENCING CONSUMER AD AVOIDANCE}

\section{INTRODUCTION}

\subsection{Social Media Advertising}

The continuous increase in consumer usage of social media has fostered a rise in advertising spend on these platforms (eMarketer, 2014). This growing use of social media as a medium for advertising has led to concerns that advertising messages might be getting lost in the 'noise' of social media content, rendering ads unproductive in commercial and behaviourchanging terms. This, in turn, often leads to the creation of ads which stride the line between edgy and offensive (Fogul, 2002; Chan, Li, Diehl \& Terlutter, 2007). However, unlike offline media platforms, social media allow users greater control over the contents of communication (Thackeray, Neiger, Hanson \& McKenzie, 2008; Mangold \& Faulds, 2009; Roehm \& Haugtvedt, 1999). This increases consumers' power and agency when confronted with commercial communications (e.g. see Denegri-Knott, 2006; Kerr, Mortimer, Dickinson \& Waller, 2012). Consumers' tendency to avoid ads is a well-established fact, both in the academic literature and among advertising professionals. This context, in which the number of adverts is growing while consumers have more capacity to avoid ads, could spell difficulties not only for advertisers, but also for the business model of most social media companies.

Confronted with the possibility that consumers may be avoiding marketing communications, advertisers may be tempted to try to gain attention through adverts that include controversial imagery. Controversial advertising refers to obscene, vulgar or provocative advertising which aims to offend or shock audiences through norm violation (Dahl, Frankenberger \& 
Manchanda, 2003). However, context sensitivities such as where, when and who views the ad circumscribe the very terms 'controversial' or 'offensive' (Fam, Waller \& Erdogan, 2004; Fam \& Waller, 2003; Phau \& Prendergast, 2001; Prendergast, Ho \& Phau 2002; Waller, 1999). Perceptions of controversy therefore extend to a broader spectrum of advertising contents, forms and suitable media (Chan et al., 2007; Phau \& Prendergast, 2001). Additionally, offensive or controversial advertising is relational and situational (Ma, 1996; Chan et al., 2007), which suggests that ads may or may not cause offense in the context audiences view them, including for example the media context (e.g. online or social media platforms). In other words, audiences may perceive an ad as offensive in one media platform but not another (Speck \& Elliott, 1997; Christy \& Haley, 2008), with varied tolerance across different media platforms (Prendergast et al., 2002; Prendergast \& Hwa, 2003). On this basis, questions arise about consumers' perceptions of ad controversy beyond the current conceptualizations that pertain to content, imagery or product. Indeed, perceptions of ad controversy can result from the interference of ads on interactive platforms, which tests or extends the ethical boundaries of taste and decency.

Nevertheless, academic research on how consumers respond to social media ads which they find offensive remains largely silent. Additionally, while much of the literature on offline ads (including controversial ads) is still relevant to ads on digital platforms, online ads are distinct from their offline counterparts (Rodgers \& Thorson, 2000), which in turn highlights the need for more specific research. This paper addresses this research gap, by analysing antecedents to the decision to avoid advertising in the context of social media. Drawing on previous research, the aim of this study is to examine the relationship between consumer ethical judgment of social media ads, perceptions of ad controversy and advertising avoidance on social media. In essence, the main objective of the paper is to identify causal 
relations between ethical judgement, perceptions of adverts, and the decision to avoid controversial ads on social media.

The findings of the study contribute to theory most notably as they extend the concept of ad controversy on social media. While the landscape of advertising in these platforms remains in flux due to their relative novelty, our study suggests that the perception of communication as controversial has an important impact on consumers' decisions to avoid adverts. Furthermore, the study also establishes the key role of ethical judgment as a moderator of the relationship between perceptions of ads as controversial and advertising avoidance on social media. This highlights that individual factors can impact perception of an advert as controversial and, thus, ad avoidance decision-making by consumers on social media. Additionally, the study's findings have key practical implications. In particular, the findings highlight how lack of attention to the contents of the adverts shown in a platform can have the effect of disengaging consumers. If systematic, this might have a negative impact on social media companies' business models, which often depend on advertising revenue. Given our findings, it is suggested that there is a role for curation of adverts shown by social media websites, in order to make sure consumers are not put off by attempts to grab their attention. The remainder of the paper discusses relevant literature, methodology, results and implications for theory and practice.

\section{CONCEPTUAL BACKGROUND}

\subsection{Advertising Avoidance}

Ad avoidance refers to "all actions by media users that differentially reduce their exposure to ad content” (Speck \& Elliott, 1997, p. 61). Early research highlights two ways in which consumers can avoid ads on traditional media, namely physical avoidance, such as leaving 
the room, and mechanical avoidance, such as switching channels or fast-forwarding ads (Abernethy, 1991). Later research identifies an additional type of advertising avoidance, namely cognitive avoidance, which refers to the act of ignoring and not viewing an ad (Speck \& Elliott, 1997). Additional research also examines these types of advertising avoidance in an online context, where mechanical avoidance can include the use of digital recorders and other mechanisms to filter out, skip or delete ads (Kelly et al., 2010; Pashkevich, Dorai-Raj, Kellar \& Zigmond, 2012). For example, Pashkevich et al. (2012) explore the inclusion of skippable video ads in YouTube (i.e. TrueView in-stream advertising), which offer consumers the option to skip the ad and view video content after five seconds. Pashkevich et al.'s (2012) findings propose that the inclusion of skippable ads reduces negative user experience with social media sites, and hence avoids negative effects on consumers' perceptions of ads.

Further, and in an online context, Cho and Cheon (2004) propose that advertising avoidance consists of cognitive, affective and behavioural components. The cognitive component entails

intentionally ignoring the ad, while the affective component suggests response in the form of negative feelings towards an ad (Cho \& Cheon, 2004). Additionally, the behavioural component is comparable to Abernethy’s (1991) physical and mechanical avoidance and consists of consumer actions that seek to avoid ads, such as leaving the room, scrolling down a page and skipping a video ad or installing an ad-blocker. Cho and Cheon’s (2004) inclusion of the affective component in advertising avoidance contributes to a better understanding of the potential for emotion to influence ad avoidance, which previous research fails to acknowledge.

\subsection{Antecedents of Advertising Avoidance}

Previous research focuses on the antecedents of advertising avoidance and attempts to 
classify them on the basis of content, media or other communication factors (Speck \& Elliott 1997). Additionally, Speck and Elliott (1997) suggest that consumers' general perceptions of ads impact ad avoidance across different media, while Rojas-Méndez, Davies and Madran (2009) identify a number of consumer demographics (i.e. gender and education) that also determine advertising avoidance. Moreover, additional factors which affect consumers' ad avoidance involve perceived irritation (Baek \& Morimoto, 2012), scepticism toward the ad (Obermiller, Spangenberg \& MacLachlan, 2005; Obermiller and Spangenberg, 1998), perceived intrusiveness (Ha, 1996; Li, Edwards \& Lee, 2002), and perceptions of advertising as disruptive (Cho \& Cheon, 2004). However, some of these factors or antecedents may overlap and their magnitude in terms of impact on ad avoidance varies depending on the media platform in question.

\subsubsection{Negative Communication Factors as Antecedents of Ad Avoidance on Social Media}

Speck and Elliott (1997) identify communication issues as antecedents of ad avoidance across different media platforms. Specifically, the authors put forward the issues of 'noise' or clutter as well as perceptions of hindrance of one's goals as key antecedents of advertising avoidance. Similarly, and in an online context, Cho and Cheon (2004) identify three factors that relate to how consumers experience ads online. The authors suggest that perceptions of goal impediment, negative experience and perceptions of ad clutter impact advertising avoidance online. Goal impediment refers to the perception that one’s goal while online (e.g., web browsing, searching for content) cannot be met as a result of online ads, hence leading to ad avoidance. In this case consumers perceive ads overall as disruptive, distracting and hindering of their search efforts. In the context of social media, consumers perform certain goal-directed functions such as socializing, connecting with friends and relatives, and sharing 
or watching specific content. Therefore, consumers will likely avoid ads which they perceive to disrupt or distract from these goals (Cho \& Cheon, 2004; Kelly et al., 2010).

Consumers also often perceive such goal-impeding or distracting ads on social media as excessive or clutter. According to Cho and Cheon (2004), and Rejón-Guardia and MartínezLópez (2014), consumers’ perception of advertising as clutter can lead to ad avoidance. Advertising clutter refers to the "presence of a large amount of non-editorial content in an editorial medium” (Ha \& McCann, 2008, p.570). Ha and McCann (2008) argue that advertising content that exceeds consumers' level of acceptance in specific media represents clutter, and leads to unfavourable perceptions of irritation due to the disruption of flow, and subsequently to advertising avoidance. As such, in the context of social media, advertising avoidance will likely occur when consumers perceive the number of ads to be excessive, as perceived ad clutter interferers with users' goals, and affects overall social media consumer experience. Concurrently, and in line with Cho and Cheon (2004), previous negative experience with advertising online, which may result in dissatisfaction or negative attitudes, also leads to ad avoidance. By extension, social media users may perceive social media advertising negatively due to previous negative experience with ads, and see no incentive for clicking on social media ads (Kelly et al., 2010). On the basis of this stream of research (Cho \& Cheon, 2004; Kelly et al., 2010; Ha \& McCann, 2008), the first hypothesis is as follows:

H1: Negative communication factors will positively impact consumer avoidance of social media ads.

That is to say, we suggest that consumers who perceive communication factors more negatively will avoid social media ads more than those who perceive communication factors positively. 


\subsubsection{Perceptions of Social Media Advertising as Controversial}

Consumers can have positive or negative ad perceptions (Chan et al., 2007), and may perceive ads as controversial (e.g. offensive, disgusting, impolite) due to the nature of the product or service being advertised, or on the basis of advertising appeals and execution styles (Dens, De Pelsmacker \& Janssens, 2008; Chan et al. 2007). For example, appeals such as sexual images, nudity, violence and fear within an ad violate norms, often lead to negative consumer perceptions (Chan et al., 2007), and subsequent avoidance of such ads. Additionally, certain controversial products (e.g. condoms, gambling) often evoke reactions of distaste, offence or even outrage given their sensitivity or moral contentiousness (Wilson \& West, 1981; Waller, 1999), which also lead to negative consumer perceptions.

However, the media in which the ad appears shape consumer perceptions of ads generally, as well as the subsequent reactions of audiences towards ads (e.g. ad avoidance). In particular, Speck and Elliott (1997) argue that one's avoidance of ads depends on categorical beliefs or perceptions about ads generally, and consumers can perceive ads as generally negatively (e.g. offensive, annoying or irritating) in one type of media but not another, leading to varied levels of ad avoidance across different media, regardless of the ad appeals or execution styles of the ads. Similarly, Chan et al. (2007) argue that perceptions of ads as controversial are context-specific including, for example, the media where the ad appears (e.g. social media). As such, advertising media can shape the extent to which consumers perceive social media advertising as generally controversial.

In this study the authors argue that the aforementioned issues that pertain to communication factors (e.g. advertising clutter, goal impediment and negative experience) in online platforms, and which hinder overall user experience, are likely to also shape additional negative perceptions of ads on social media, including general perceptions of ads as 
controversial. The authors suggest consumers' general negative perceptions of ads revolve around ads' perceived worth and their intrusive or interfering nature, as such perceptions depend on the interactive media where ads appear rather than advertising content (e.g. ad execution and appeals) per se, which can also lead to ad avoidance. Therefore, communication factors (section 2.2.1) may shape perceptions of social media advertising as generally controversial (e.g. offensive, impolite, uncomfortable, irritating), which in turn will lead to consumer ad avoidance on social media. Hence:

H2: Negative Communication factors will positively impact perceptions of social media advertising as generally controversial.

Thus, we suggest that consumers who perceptive communication factors more negatively will perceive social media advertising as generally controversial. Additionally:

H3: Perceptions of social media advertising as generally controversial will positively impact consumer avoidance of social media ads.

Therefore, we argue that consumers who have stronger perceptions of social media advertising as controversial will avoid social media ads more than those who do not perceive social media ads as controversial.

\subsubsection{Consumers' Ethical Judgment of Ads}

Ethical judgment refers to the cognitive process through which an individual assesses which actions are morally correct (McMahon \& Harvey, 2006; Nguyen \& Biderman, 2008; Trevino, 1992). According to Jones (1991), ethical judgment represents a mechanism by which an individual's moral beliefs have a bearing on their action. Following the perception that an 
event or aspect of the surrounding environment may involve a moral dilemma or issue, an ethical judgment takes place about what should be done. In other words, ethical judgment precedes action (Nguyen \& Biderman, 2008).

Previous research investigates the link between ethical judgment and behaviour mainly in organizational research, albeit it is possible to extend it to this study, too. Jones (1991) argues that individual ethical awareness leads to ethical judgment, ethical intent and consequently ethical behaviour, while factors such as individual (e.g., values, personality) and situational (e.g., organizational culture) characteristics moderate such a process. Therefore, ethical judgment is an important element of intent and behaviour, as it enables decision-makers to evaluate ethical dilemmas and challenges as they arise in specific contexts (Jones, 2009). In the context of consumer responses to marketing communications, few studies specifically investigate the impact of consumer ethical judgment of advertising. However, Simpson, Brown and Widding II (1998) argue that consumers' ethical perceptions and evaluations affect their responses to ads in a variety of contexts. In particular, the authors examine the effects of consumer ethical judgment of advertising on consumer responses to ads and argue that ads which consumers judge as unethical impact advertising responses such as attitude towards the ad, attitude toward the brand and purchase intention (Simpson, Brown \& Widding II, 1998; also Beltramini, 2006).

In the context of social media, Kerr et al. (2012) suggest that consumers will use their online platforms to judge, promote or give their moral opinions about controversial ads, including those ads relevant authorities ban. Therefore, ethical judgments (Nguyen \& Biderman, 2008; Reidenbach \& Robin, 1988; 1990) have the potential to shape consumers’ perceptions of ads as controversial, as well as ad avoidance on social media. Previous research (section 2.2.2) shows that controversial advertising can result in negative perceptions (Tinkham \& Weaver- 
Lariscy, 1994; Waller, 1999; Waller, 2005). In line with this stream of research, this paper argues that the more consumers judge social media ads as ethical, the less they will perceive ads negatively. Therefore, the authors expect ethical judgment to negatively affect perceptions of social media ads as generally controversial (due to their offensive and impolite value). At the same time, the authors expect ethical judgment to directly impact advertising avoidance on social media. As such, the more ethical (e.g. fair, acceptable) consumers perceive the ads to be, the less they will avoid ads on social media. Hence:

H4: Consumers' ethical judgment of social media ads will negatively impact perceptions of social media ads as generally controversial.

Therefore, we suggest that the more ethical consumers judge social media ads to be, the less controversial such ads will be perceived to be. Also:

H5: Consumers' ethical judgment of social media ads will negatively impact advertising avoidance of such ads.

Thus, we argue that the more ethical consumers judge social media ads to be, the less consumers will avoid such ads.

Moreover, consumers' ethical judgment of social media ads may impact the relationship between perceptions of ads as controversial and ad avoidance. Although general perceptions of social media ads as offensive, impolite and irritating may lead to avoidance of such ads, there are instances where ethical judgment may influence this relationship: consumers may have generally negative perceptions of social media ads, but may choose not to avoid them because they may think that it is fair for social media to run ads, as social media are usually free to use. Therefore, while perceptions of social media ads as generally controversial could lead to ad avoidance, social media users may instead choose not to avoid ads on social media. 
This is because consumers may perceive social media ads as what enables social media to remain free for users and therefore viewing the ad would be judged as morally acceptable. Thus, the authors hypothesize that:

H6: Consumers' ethical judgment of social media ads will moderate the relationship between perceptions of social media ads as generally controversial and avoidance of social media ads.

[Insert Figure 1 Here]

The following sections discuss the methodology of the research, as well as the analysis and results.

\section{METHODOLOGY}

\subsection{Methods and Sample}

The quantitative study involved designing, piloting and launching an online survey questionnaire. First, five academic experts reviewed the questionnaire. A university web portal then announced the call for pilot research participants, which resulted in a nonprobabilistic sample composed of 133 professional support staff. The researchers subsequently refined the online survey questionnaire and collected the main data set through a professional online consumer panel service. Participants received nominal incentives for taking part in the survey. The quota sample consisted of 290 UK-based respondents above the age of 18, who described themselves as social media users, in full-time employment. The research team excluded incomplete questionnaires from the analysis, which resulted in a final sample of 273 usable questionnaires. 38\% of respondents were male and $62 \%$ were female. 
There was a good spread of age distribution, with $38 \%$ of the total sample between the ages of 26 and 35, 25\% between 46 and 55, 21\% between 36 and 45, 8\% between 18 and 25, and 8\% between 56 and 65. There were diverse levels of educational achievement, with 19\% of the sample having GSCEs, 35\% possessing further education (A-level or equivalent), 30\% having undergraduate degrees and 16\% holding postgraduate degrees. Table 1 shows the sample demographics.

[Insert Table 1 Here]

\subsection{Measures}

A number of scales were selected from existing literature and adapted for the purposes of the study. To measure ethical judgment of social media ads the study adapted a scale from Reidenbach and Robin's (1990) and Simpson et al.'s (1998) works, with items gauged on social media ads in general. The measure of communication factors (e.g. ads on social media as intrusive, disruptive, excessive), and ad avoidance (e.g. cognitive, affective, behavioural) were based on Cho and Cheon (2004) and adapted to the context of social media (e.g. I hate banner ads on social media; clicking on social media ads does not help me improve my experience of social media; ads interrupt the flow of my social media experience). Finally, to capture perceptions of social media advertising as generally controversial the study used 13 items based on Chan et al.'s (2007) work. While the study focuses only on negative assessments of social media ads, which trigger perceptions of controversy, the researchers included both positive and negative items in the questionnaire to avoid presenting the potential respondents only with negative adjectives, in line with Chan et al.’s (2007) work. In particular, the survey questionnaire included six positive and seven negative items, and respondents we asked to rate their overall belief about social media ads. The questionnaire 
presented measures to respondents as 7-point Likert scales and the researchers reverse-scored some of the items for calculation purposes.

\section{ANALYSIS AND RESULTS}

\subsection{Reliability Assessment}

Reliability analysis indicated acceptable Cronbach alpha levels (Nunnally, 1978) for all scales used except that of ethical judgment. To remedy the problem and to achieve internal consistency, three items from the ethical judgment scale with very low item-to-total correlations were dropped, in line with research (Finn and Kayande, 2004). The items in question asked participants how much they agreed that social media adverts consisted of a violation of an unspoken promise of good content; a violation of an unspoken contract of good content; or if they were acceptable to my [the respondent's] family. Subsequently, the researchers used overall measures for all constructs for parsimony purposes, but also due to the theoretical support for conceptual links among the items of each construct ${ }^{1}$ (Ha \& McCann, 2008; Christy \& Haley, 2008). To verify this in the data the research team also performed exploratory factor analysis. The results show that items measuring each construct load on a single respective factor. Table 2 presents reliability statistics.

\section{[Insert Table 2 Here]}

\subsection{Measurement Model}

\footnotetext{
${ }^{1}$ Previous research suggests a conceptual link among perceptions of goal impediment, ad clutter and prior negative experience, indicating that consumers view clutter as impeding their functional goals while on social media (Ha \& McCann, 2008), possibly leading to negative experience as consumers can perceive ads as useless.
} 
The researchers used a two-step analytical procedure, in line with Anderson and Gerbing (1988). First, the data was subjected to Confirmatory Factor Analysis (CFA). CFA allows for the exploration of which observed variables relate to latent factors, as well as confirmation that a set of variables define those factors (Schumacker \& Lomax, 2004). The researchers completed the CFA using Lisrel 9.10 (Jöreskog \& Sörbom, 2013). Initial CFA results returned the following model fit statistics values: $\chi 2(65)=100.83, p=0.000, \operatorname{RMSEA}=0.04$; $\mathrm{NFI}=0.96 ; \mathrm{NNFI}=0.98$ and $\mathrm{CFI}=0.98$. There is evidence of a good $\chi 2 / \mathrm{df}$ ratio, which Dion (2008) suggests should be less than 3, as well as good NFI and CFI ratios, which should be over 0.95. As a result, the researchers consider the model to have satisfactory fit. Subsequently, all constructs were tested for discriminant validity by comparing the factors' Average Variance Extracted (AVE) scores with the square of correlations between factors (Fornell \& Larcker, 1981). All AVE scores were greater than the square of correlations between factors, thus demonstrating discriminant validity (Table 3).

\section{[Insert Table 3 Here]}

\subsection{Structural Model}

The model was tested in Lisrel 9.10 (Jöreskog \& Sörbom, 2013), using the maximum likelihood (ML) estimation method and the covariance matrix as input data. In terms of fit statistics, the estimated structural model presents a satisfactory chi-square value: $\chi 2(228)=$ 547.78, $\mathrm{p}=0.00$. The model also produces a RMSEA value of 0.06 , above the accepted value of 0.05 (Dion, 2008; Schumacker \& Lomax, 2004; Ullman \& Bentler, 2013). Given that $\chi 2$ depends on sample size, the researchers used $\chi 2 / \mathrm{df}$ as an alternative measure of model fit. The quotient is 2.40, below the recommended value of 3 (Dion, 2008). In terms of the goodness of fit statistic, the model presents generally satisfactory fit scores. In terms of the 
normed fit index, non-normed fit index and comparable fit index, which account for the complexity of the model (Hox \& Bechger, 1998), the model produces scores of NFI=0.96, NNFI $=0.97$ and $\mathrm{CFI}=0.98$, all above the recommended 0.95 level. The model also produces an RMSEA score of 0.07. Recommendations about the appropriate level for this index vary significantly (see Hooper, Coughlan \& Mullen, 2008), with authors recommending between 0.08 and 0.10 (MacCallum, Brown \& Sugawara, 1996), close to 0.06 (Hu \& Bentler, 1999) or no higher that 0.07 (Steiger, 2007). As a result, the researchers accept that the RMSEA value for the model indicates good fit, especially bearing in mind that RMSEA penalizes more complex models. Below the paper presents the parameter estimates within the complete structural model, which test hypotheses H1 to H6.

\subsection{Hypotheses Test}

The analysis supports all of the direct effect hypotheses. The study's tests confirm hypothesis H1 with a positive, significant estimate of 0.49 . This result means that negative communication factors on social media increase the likelihood of consumer avoidance of social media ads. Similarly, the analysis supports hypothesis H2 with a positive, significant estimate of 0.55 . This result suggests that negative communication factors on social media are strongly related to perceptions of social media advertising as generally controversial. Additionally, hypothesis H3 presents a positive, significant coefficient of 0.13 , which supports the proposition that perceptions of social media advertising as generally controversial lead to likelihood of consumer avoidance of social media ads. This result indicates that, all other things being equal, consumers are more likely to avoid social media ads if they perceive such ads as generally controversial. Furthermore, a high score of ethical judgment of social media ads reduces the perceptions of social media advertising as generally 
controversial, which supports hypothesis $\mathrm{H} 4$ with a negative, significant coefficient estimate of -0.14 . Finally, hypothesis H5 presents a negative significant estimate of -0.18 . Thus, this result suggests that a high score of ethical judgment of social media ads reduces consumer avoidance of social media ads.

[Insert Table 4 Here]

\subsection{Moderation Test}

The theoretical model (Figure 1) proposes a moderation effect (hypothesis H6). Moderator variables serve as changers of the relationships in systems: depending on their value, the direct relationship between independent and dependent variables will vary (Little et al., 2007). The classic moderator effect involves investigating the effect of a third variable, the effect of which is to partition the independent variable into subgroups and estimate their different effects on the dependent variable (Baron \& Kenny, 1986). In cases where the theorized moderator variable is continuous, the approach can be to re-code the moderator into a discrete variable, creating two or more groups in the process; researchers can then achieve the moderation analysis by comparing the structural models for each group (Sauer \& Dick, 1993). While researchers can also apply this approach to structural equation modelling, creating independent groups from a continuous variable shows three disadvantages: first, there is a degree of loss of information due to simplification of the variable and the tests will therefore have less statistical power. Second, an arbitrary split of the sample according to the score of a variable may create groups which do not exist in reality, making the analysis meaningless. Third, researchers can observe differences which are a function of the chosen cut-off point, rather than the moderator effect (Bagozzi, Baumgartner \& Yi, 1992). 
The alternative approach is to include an interaction variable in the SEM, constructed as the product of the independent variable and the moderator variable (Cortina, Chen, \& Dunlap, 2001; Hair, Black, Babin \& Anderson, 2010; Sauer \& Dick, 1993). However, this approach presents limitations, as the error terms are not defined. Researchers can apply a number of methods to produce meaningful error terms. In this paper the authors used the unconstrained approach to interaction modelling (Marsh, Wen \& Hau, 2004): the researchers treated the interaction term as a latent variable, and estimated it using the mean-centred products of perceptions of social media advertising as generally controversial and ethical judgment; this allows the error terms of the interaction to be unconstrained.

However, in estimating the structural model researchers must use mean-centred indicators when estimating the moderator variable, the indicator variable and the error term (Steinmetz, Davidov \& Schmidt, 2011). After this, researchers can estimate the model by specifying the structural path between the moderator (interaction) term and the dependent variable. Moderation support exists if the relationship between the moderator and the dependent variable is significant (Hair et al., 2010). The analysis shows a significant, positive coefficient of 0.08 for the relationship between ethical judgment of social media ads, and the interaction of perceptions of social media advertising as generally controversial and consumer avoidance of such ads. At first, this result seems to support H6. However, given hypotheses $\mathrm{H} 4$ and $\mathrm{H} 5$ in particular, the authors expected a negative result for the H6 coefficient, which the data does not show. Therefore, although the moderation effect of ethical judgment on the interaction between perceptions of social media advertising as generally controversial and consumer avoidance of social media ads is significant, this interaction has the effect of increasing rather than decreasing consumer avoidance of social media ads, which counters the researchers' original, predictive explanation regarding the moderation effect. Figure 2 shows the complete structural model with results. 
[Insert Figure 2 Here]

\section{DISCUSSION AND IMPLICATIONS}

The results of the study provide support for the research hypotheses and highlight the key role of ethical judgment in consumer avoidance of advertising on social media. The results complement previous research (Cho \& Cheon, 2004; Ha \& McCann, 2008), by indicating that social media users avoid ads on social media because they view them as useless clutter and impeding social media goals (i.e. negative communication factors, as articulated in H1). Similarly, research results show that consumers view social media ads as generally controversial (M: 4.59, SD: 1.08), and this leads to consumer avoidance of such ads (H3), which in turn builds on previous research (Christy \& Haley, 2008; Dens et al., 2008; Prendergast et al., 2002; Prendergast \& Hwa, 2003. The results highlight that ads on social media must be seen as useful and informative, as opposed to useless and impeding, as such perceptions will affect the overall worth of such ads to consumers (Ducoffe, 1995), leading to perceptions of such ads as uncomfortable or impolite (e.g. controversial), and subsequently to avoidance of social media ads. Our respondents exhibit negative perceptions about social media ads and mean values show that individuals highly avoid ads while on social media. Indeed, individuals ignore ads by not paying attention and attempt to behaviourally avoid them by scrolling down, leaving the page, or opening new browsers.

Furthermore, findings highlight the role of ethical judgment in shaping consumer perceptions of social media advertising as generally controversial, but also in leading consumers to avoid social media ads. Specifically, the research suggests that the more ethical consumers judge social media ads to be, the less they are likely to avoid such ads (H5), and to perceive such 
ads as generally controversial (H4). Finally, results highlight the moderating role of ethical judgment in the relationship between perceptions of social media ads as generally controversial and consumer avoidance of social media ads (H6). However, the moderation does not occur in the expected direction. Findings suggest that ethical judgment of social media ads magnifies the relationship between those two constructs (figure 2); that is, in cases where consumers might consider social media advertising as controversial but ethical (i.e. where consumers accept social media ad controversy as fair, given that such ads enable social media to remain free for consumers), ethical judgment will lead to more rather than less avoidance of social media ads when such ads are generally perceived as controversial. Concurrently, our analysis shows that, in the context of social media, the more ethical consumers perceive the controversial ads to be, the more consumers will avoid such ads.

\subsection{Theoretical Implications}

This work extends previous research in the area of consumer ethics and advertising avoidance using a quantitative study. At the same time, it advances knowledge in the domain of advertising avoidance in a social media context. In particular, this research contributes to theory by expanding the conceptualization of controversy in advertising stemming from negative communication factors such as cluttering and interfering social media ads, as well as from media context (i.e. social media). Another notable theoretical contribution of this study is that it demonstrates the role of ethical judgment of social media ads as a moderator of the relationship between perceptions of social media advertising as generally controversial and consumer avoidance of such ads on social media, which yields relevant implications for marketers and advertisers. 


\subsection{Practical Implications}

This study suggests that when consumers perceive social media advertising as generally controversial, but nevertheless judge such ads to be ethical, consumers are even more likely to avoid social media ads. This result does question the efficacy of social media advertising generally, particularly where consumers might perceive such ads as offensive, annoying or irritating due to the media being used. This finding is of notable interest to marketers and advertisers, as it suggests the need to test the suitability of their marketing communication campaigns to social media platforms, irrespective of the ad appeals or execution styles such ads might contain, in order to prevent ad avoidance. In particular, the results show that targeting consumers via social media will not assure their attention. In fact, the opposite is more likely to occur when social media users generally perceive social media advertising as controversial as well as ethical. As Simpson et al. (1998) argue, this finding highlights the importance of evaluating consumer ethical judgments of social media ads before running such ads, given that avoidance of social media ads will impact social media ad effectiveness (Bellman, Schweda \& Varan, 2010; Bryce \& Yalch, 1993; Pashkevich et al., 2012; Zufryden, Pedrick \& Sankaralingam, 1993).

\subsection{Limitations and Future Research}

Like any other study this research is not free of limitations. This study relies on consumers' self-reported measures of negative communication factors on social media, consumer avoidance of social media ads, perceptions of social media advertising as generally controversial, and consumer ethical judgment of social media ads, which inherently present limitations. Also, unlike previous studies, this research does not gauge measures on specific ads to capture key constructs. Thus, future research can make use of such stimuli and experimental designs, employing both commercial and non-profit messages, in order to 
further examine the research results this paper presents. Researchers may also wish to apply the model in the context of specific social media platforms such as Facebook or YouTube (e.g. captive versus self-paced media), for example, which may present various levels of ad avoidance. Finally, future studies can use a more balanced sample in terms of age spread of social media users, as ours was biased towards 30+ age ranges. Future studies can also seek to investigate specific social media platforms vis-à-vis diverse cultural contexts in order to validate this paper's theoretical model. 


\section{References}

Abernethy, A. M. (1991). Television exposure: Programs vs. advertising. Current Issues and Research in Advertising, 13(1-2), 61-77. doi:10.1080/01633392.1991.10504959

Anderson, J. C., \& Gerbing, D. W. (1988). Structural equation modelling in practice: A review and recommended two-step approach. Psychological Bulletin, 103(3), 411-423. doi:10.1037/0033-2909.103.3.411

Baek, T. H., \& Morimoto, M. (2012). Stay away from me. Journal of Advertising, 41(1), 5976. doi:10.2753/JOA0091-3367410105

Bagozzi, R. P., Baumgartner, H., \& Yi, Y. (1992). State versus action orientation and the theory of reasoned action: An application to coupon usage. Journal of Consumer Research, 18(4), 505-518. doi: http://www.jstor.org/stable/2489262

Baron, R. M., \& Kenny, D. A. (1986). The moderator-mediator variable distinction in social psychological research: Conceptual, strategic, and statistical considerations. Journal of Personality and Social Psychology, 51 (6), 1173-1182. doi:10.1037/00223514.51.6.1173.

Bellman, S., Schweda, A., \& Varan, D. (2010). The residual impact of avoided television advertising. Journal of Advertising, 39(1), 67-82. doi:10.2753/JOA0091-3367390105

Beltramini, R. F. (2006). Consumer believability of information in direct-to-consumer (DTC) advertising of prescription drugs. Journal of Business Ethics, 63(4), 333-343. doi:10.1007/s10551-005-4711-2

Bryce, W. J., \& Yalch, R. F. (1993). Hearing versus seeing: A comparison of consumer learning of spoken and pictorial information in television advertising. Journal of Current Issues and Research in Advertising, 15(1), 1-20. doi:10.1080/10641734.1993.10504993

Chan, K., Li, L., Diehl, S., \& Terlutter, R. (2007). Consumers' response to offensive advertising: A cross cultural study. International Marketing Review, 24(5), 606-628. doi:10.1108/02651330710828013

Cho, C.-H., \& Cheon, H. J. (2004). Why do people avoid advertising on the Internet? Journal of Advertising, 33 (4), 89-97. doi:10.1080/00913367.2004.10639175

Christodoulides, G. (2009). Branding in the post-Internet era. Marketing Theory, 9 (1), 141144. doi:10.1177/1470593108100071. 
Christodoulides, G., \& Jevons, C. (2011). The voice of the consumer speaks forcefully in brand identity: User-generated content forces smart marketers to listen. Journal of Advertising Research, 51 (1), 101-111. doi:10.2501/JAR-51-1-101-111.

Christy, T. P., \& Haley, E. (2008). The influence of advertising context on perceptions of offense. Journal of Marketing Communications, 14(4), 271-291. doi:10.1080/13527260802141272

Cortina, J. M., Chen, G., \& Dunlap, W. P. (2001). Testing interaction effects in LISREL: examination and illustration of available procedures. Organization Research Methods, 4(4), 324-360. doi: 10.1177/109442810144002

Dahl, D. W., Frankenberger, K. D., \& Manchanda, R. V. (2003). Does it pay to shock? Reactions to shocking and nonshocking advertising content among university students. Journal of Advertising Research, 43(03), 268-280. doi:10.1017/S0021849903030332

Denegri-Knott, J. (2006). Consumers behaving badly: Deviation or innovation? Power struggles on the web. Journal of Consumer Behaviour, 5 (1), 82-94. doi:10.1002/cb.45

Dens, N., De Pelsmacker, P., \& Janssens, W. (2008). Exploring consumer reactions to incongruent mild disgust appeals. Journal of Marketing Communications, 14(4), 249269. doi:10.1080/13527260802141231

Dion, P. A. (2008). Interpreting structural equation modelling results: A reply to Martin and Cullen. Journal of Business Ethics, 83(3), 365-368. doi:10.1007/s10551-007-9634-7

Drumwright, M. E., \& Murphy, P. E. (2009). The current state of advertising ethics: Industry and academic perspectives. Journal of Advertising, 38(1), 83-108. doi:10.2753/JOA0091-3367380106

Ducoffe, R. H. (1995). How consumers assess the value of advertising. Journal of Current Issues \& Research in Advertising, 17(1), 1-18.

eMarketer. (2014, May 29). Online ad spending in Europe topped €27 billion in 2013. Retrieved June 11, 2014, from http://www.emarketer.com/Article/Online-AdSpending-Europe-Topped-euro27-Billion-2013/1010870

Fam, K. S., \& Waller, D. S. (2003). Advertising controversial products in the Asia Pacific: What makes them offensive? Journal of Business Ethics, 48(3), 237-250. doi:10.1023/B:BUSI.0000005785.29778.83

Fam, K. S., Waller, D. S., \& Erdogan, B. Z. (2004). The influence of religion on attitudes towards the advertising of controversial products. European Journal of Marketing, 38(5/6), 537-555. doi:10.1108/03090560410529204 
Finn, A., \& Kayande, U. (2004). Scale modification: alternative approaches and their consequences. Journal of Retailing, 80(1), 37-52.

Fornell, C., \& Larcker, D. F. (1981). Evaluating structural equation models with unobservable variables and measurement error. Journal of Marketing Research, 18 (1), 39-50. doi:http://www.jstor.org/stable/3151312

Google. (2015). Sensitive ad categories. Retrieved February 28, 2015, from https://support.google.com/adsense/answer/3016445?hl=en.

Gritten, A. (2007). Forum-media proliferation and demands for new forms of research. International Journal of Market Research, 49(1), 15-23. doi:https://www.mrs.org.uk/ijmr_article/article/84627

Ha, L. (1996). Observations. Advertising clutter in consumer magazines: Dimensions and effects. Journal of Advertising Research, 36(4), 76-84. doi:http://www.jar.warc.com/ArticleCenter/default.asp?ID=6188\&Type=Article

Ha, L., \& McCann, K. (2008). An integrated model of advertising clutter in offline and online media. International Journal of Advertising, 27 (4), 569-592. doi:10.2501/S0265048708080153

Hair, J. F., Black, W. C., Babin, B. J., \& Anderson, R. E. (2010). Multivariate data analysis. 7th ed. Upper Saddle River, NJ: Prentice Hall.

Hooper, D., Coughlan, J., \& Mullen, M. R. (2008). Structural Equation Modelling: Guidelines for Determining Model Fit. Electronic Journal of Business Research Methods, 6(1), 53-60. doi:http://www.ejbrm.com/volume6/issue1/p53

Hox, J. J., \& Bechger, T. M. (1998). An introduction to structural equation modelling. Family $\begin{array}{llll}\text { Science } & \text { Review, } & \text { 354-373. }\end{array}$ doi:http://socserv.socsci.mcmaster.ca/jfox/Courses/Oxford-2006/SEMs-notes.pdf

Hu, L.T., \& Bentler, P.M. (1999). Cutoff Criteria for Fit Indexes in Covariance Structure Analysis: Conventional Criteria Versus New Alternatives. Structural Equation Modelling, 6(1), 1-55. doi:10.1080/10705519909540118

Jones, D. A. (2009). A novel approach to business ethics training: Improving moral reasoning in just a few weeks. Journal of Business Ethics, 88(2), 367-379. doi:10.1007/s10551008-9969-8

Jones, T. M. (1991). Ethical decision making by individuals in organizations: An issue contingent model. Academy of Management Review, 16(2), 366-395.

doi:10.5465/AMR.1991.4278958 
Jöreskog, K., \& Sörbom, D. (1989). Lisrel 7: A guide to the program and applications. SPSS, Chicago, Ill.

Jöreskog, K., \& Sörbom, D. (2013). Lisrel. Scientific software international, Inc.

Kane, G. C., Alavi, M., Labianca, G., \& Borgatti, S. P. (2014). What's different about social media networks? A framework and research agenda. MIS Quarterly, 38 (1), 275-304. doi: http://misq.org/what-s-different-about-social-media-networks-a-frameworkandresearch-agenda.html

Kaplan, A. M., \& Haenlein, M. (2010). Users of the world, unite! The challenges and opportunities of social media. Business Horizons, 53 (1), 59-68. doi:10.1016/j.bushor.2009.09.003.

Kelly, L., Kerr, G., \& Drennan, J. (2010). Avoidance of advertising in social networking sites: The teenage perspective. Journal of Interactive Advertising, 10(2), 16-27. doi:10.1080/15252019.2010.10722167

Kerr, G., Mortimer, K., Dickinson, S., \& Waller, D. S. (2012). Buy, boycott or blog: Exploring online consumer power to share, discuss and distribute controversial advertising messages. European Journal of Marketing, 46 (3/4), 387-405. doi:10.1108/03090561211202521.

Li, H., Edwards, S. M., \& Lee, J.-H. (2002). Measuring the intrusiveness of advertisements: Scale development and validation. Journal of Advertising, 31(2), 37-47. doi:10.1080/00913367.2002.10673665

Little, T. D., Card, N. A., Bovaird, J. A., Preacher, K. J., \& Crandall, C. S. (2007). Structural equation modelling of mediation and moderation with contextual factors. In T. D. Little, J. A. Bovaird, \& N. A. Card (eds.), Modelling Contextual Effects in Longitudinal Studies (pp. 207-230). Laerence Erlbaum.

MacKenzie, S. B., \& Lutz, R. J. (1989). An empirical examination of the structural antecedents of attitude toward the ad in an advertising pretesting context. Journal of Marketing, 53 (2), 48-65. doi:10.2307/1251413.

Manceau, D., \& Tissier-Desbordes, E. (2006). Are sex and death taboos in advertising? An analysis of taboos in advertising and a survey of French consumer perceptions. International Journal of Advertising, 25(1), 9-33. doi:10.1080/02650487.2006.11072949

Mangold, W. G., \& Faulds, D. J. (2009). Social media: The new hybrid element of the promotion mix. Business Horizons, 52(4), 357-365. doi:10.1016/j.bushor.2009.03.002

Marsh, H. W., Wen, Z., \& Hau, K.T. (2004). Structural equation models of latent 
interactions: Evaluation of alternative estimation strategies and indicator construction. Psychological Methods, 9 (3), 275-300. doi:10.1037/1082-989X.9.3.275.

McMahon, J. M., \& Harvey, R. J. (2006). An analysis of the factor structure of Jones’ moral intensity construct. Journal of Business Ethics, 64(4), 381-404. doi:10.1007/s10551006-0006-5

Nguyen, N. T., \& Biderman, M. D. (2008). Studying ethical judgments and behavioural intentions using structural equations: Evidence from the multidimensional ethics scale. Journal of Business Ethics, 83(4), 627-640. doi:10.1007/s10551-007-9644-5

Nunnally, J. C. (1978). Psychometric theory (2nd ed.). McGraw-Hill, New York.

Obermiller, C., \& Spangenberg, E. R. (1998). Development of a scale to measure consumerskepticism toward advertising. Journal of Consumer Psychology, 7(2), 159186. doi:10.1207/s15327663jcp0702_03

Obermiller, C., Spangenberg, E., \& MacLachlan, D. L. (2005). Ad skepticism: The consequences of disbelief. Journal of Advertising, 34(3), 7-17. doi:10.1080/00913367.2005.10639199

Pashkevich, M., Dorai-Raj, S., Kellar, M., \& Zigmond, D. (2012). Empowering online advertisements by empowering viewers with the right to choose: The relative effectiveness of skippable video advertisements on YouTube. Journal of Advertising Research, 52(4), 451-457. doi:http://jar.warc.com/ArticleCenter/default.asp?ID=98499\&Type=Article

Phau, I., \& Prendergast, G. (2001). Offensive advertising: A view from Singapore. Journal of Promotion Management, 7(1-2), 71-90. doi:10.1300/J057v07n01_06

Prendergast, G., \& Hwa, H. C. (2003). An Asian perspective of offensive advertising on the web. International Journal of Advertising, 22(3), 393-411. doi:10.1080/02650487.2003.11072860

Prendergast, G., Ho, B., \& Phau, I. (2002). A Hong Kong view of offensive advertising. Journal of Marketing Communications, 8(3), 165-177. doi:10.1080/13527260210147342

Reidenbach, R. E., \& Robin, D. P. (1988). Some initial steps toward improving the measurement of ethical evaluations of marketing activities. Journal of Business Ethics, 7(11), 871-879. doi:10.1007/BF00383050

Reidenbach, R. E., \& Robin, D. P. (1990). Toward the development of a multidimensional scale for improving evaluations of Business Ethics. Journal of Business Ethics, 9(8), 639-653. doi:10.1007/BF00383391 
Rejón-Guardia, F., \& Martínez-López, F. J. (2014). An integrated review of the efficacy of Internet advertising: Concrete approaches to the banner ad format and the context of social networks. In Handbook of Strategic e-Business Management (pp. 523-564). Springer Berlin Heidelberg.

Rodgers, S., \& Thorson, E. (2000). The interactive advertising model: How users perceive and process online ads. Journal of Interactive Advertising, 1(1), 42-61.

Roehm, H. A., \& Haugtvedt, C. P. (1999). Understanding interactivity of cyberspace advertising. In D. W. Schumann \& E. Thorson (Eds.), Advertising and the World Wide Web. Lawrence Erlbaum, Mahwah, N.J.

Rojas-Méndez, J. I., Davies, G., \& Madran, C. (2009). Universal differences in advertising avoidance behaviour: A cross-cultural study. Journal of Business Research, 62(10), 947- 954. doi:10.1016/j.jbusres.2008.08.008

Sabri, O., \& Obermiller, C. (2012). Consumer perception of taboo in ads. Journal of Business Research, 65(6), 869-873. doi:10.1016/j.jbusres.2011.01.009

Sauer, P. L., \& Dick, A. (1993). Using moderator variables in structural equation models. Advances in Consumer Research, 20, 636-640. doi: http://acrwebsite.org/volumes/7532/volumes/v20/NA-20

Schumacker, R. E., \& Lomax, R. G. (2004). A beginner's guide to structural equation modelling. Lawrence Erlbaum Associates, Mahwah, N.J.

Schutz, D. E. (2006). IMC is do or die in new pull marketplace. Marketing News, 40(13), 7. doi:http://connection.ebscohost.com/c/articles/22045570/imc-do-die-newpullmarketplace

Simpson, P. M., Brown, G., \& Widding II, R. E. (1998). The association of ethical judgment of advertising and selected advertising effectiveness response variables. Journal of Business Ethics, 17(2), 125-136. doi:10.1023/A:1005798210285

Speck, P. S., \& Elliott, M. T. (1997). Predictors of advertising avoidance in print and broadcast media. Journal of Advertising, 26(3), 94-104. doi:http://www.jstor.org/stable/4189042

Steiger, J.H. (2007). Understanding the limitations of global fit assessment in structural equation modelling. Personality and Individual Differences, 42(5), 893-98. doi:10.1016/j.paid.2006.09.017

Steinmetz, H., Davidov, E., \& Schmidt, P. (2011). Three approaches to estimate latent interaction effects: Intention and perceived behavioural control in the theory of planned 
behaviour. Methodological Innovations Online, 6 (1), 95-110. doi:10.4256/mio.2010.0030.

Thackeray, R., Neiger, B. L., Hanson, C. L., \& McKenzie, J. F. (2008). Enhancing promotional strategies within social marketing programs: Use of web 2.0 social media. Health Promotion Practice, 9 (4), 338-343. doi:10.1177/1524839908325335.

Tinkham, S. F., \& Weaver-Lariscy, R. A. (1994). Ethical judgments of political television commercials as predictors of attitude toward the ad. Journal of Advertising, 23 (3), 4357. doi:10.1080/00913367.1994.10673449.

Trevino, L. K. (1992). Moral reasoning and business ethics: Implications for research, education, and management. Journal of Business Ethics, 11(5-6), 445-459. doi:10.1007/BF00870556

Ullman, J. B., \& Bentler, P. M. (2013). Structural equation modelling. In I. B. Weiner (Ed.), Handbook of Psychology (2nd ed., pp. 661-690). Wiley, Hoboken, N.J.

Waller, D. S. (1999). Attitudes towards offensive advertising: An Australian study. Journal of Consumer $\quad$ Marketing, 288-294. doi:http://dx.doi.org/10.1108/07363769910271513

Waller, D. S. (2005). A proposed response model for controversial advertising. Journal of Promotion Management, 11(2-3), 3-15. doi:10.1300/J057v11n02_02

Wilson, A., \& West, C. (1981). The marketing of “unmentionables”. Harvard Business Review, 59(1), 91-102.

Zufryden, F. S., Pedrick, J. H., \& Sankaralingam, A. (1993). Zapping and its impact on brand purchase behaviour. Journal of Advertising Research, 33(1), 58-66. doi:http://psycnet.apa.org/psycinfo/1993-31650-001 


\section{Figures}

Figure 1: Structural Model and Hypotheses

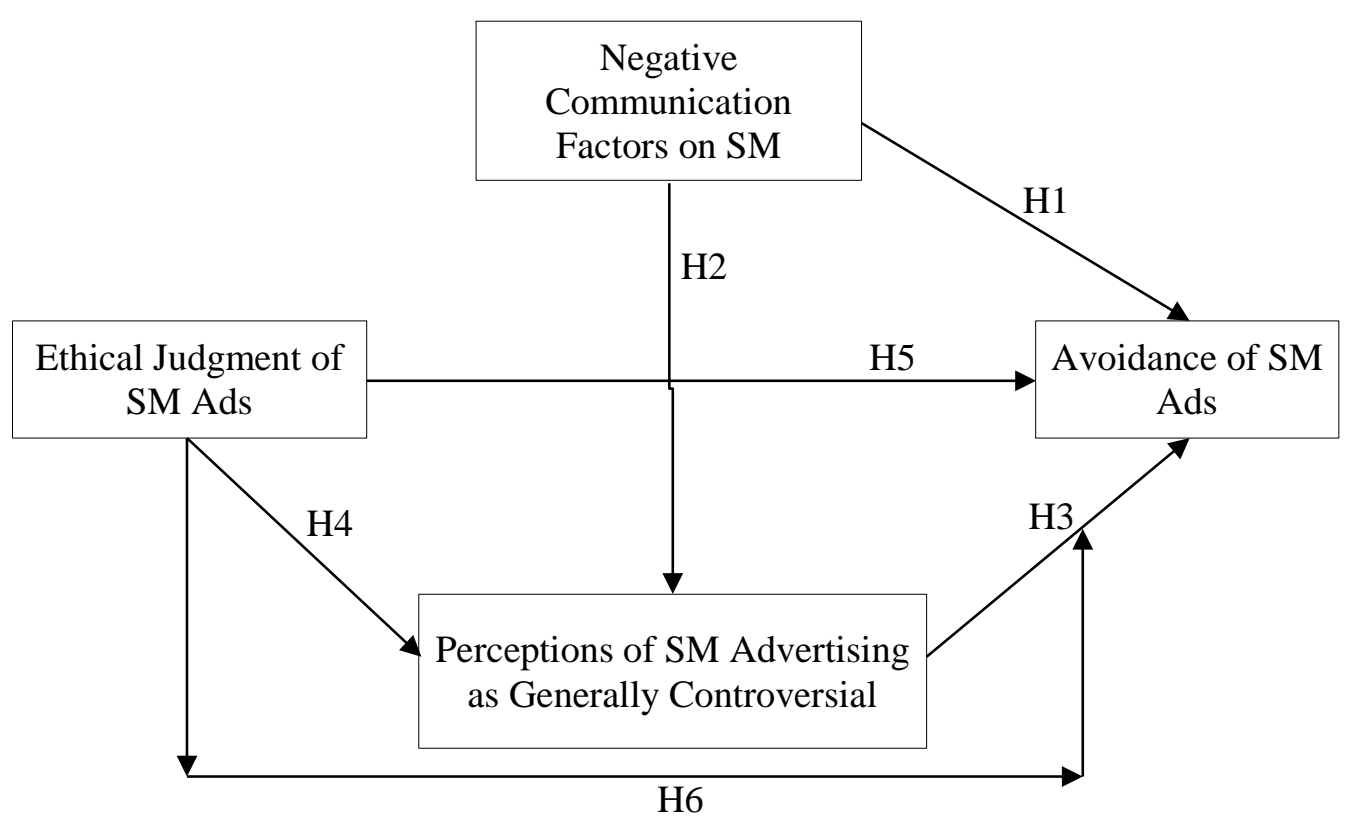


Figure 2: Structural Model and Coefficient Estimates

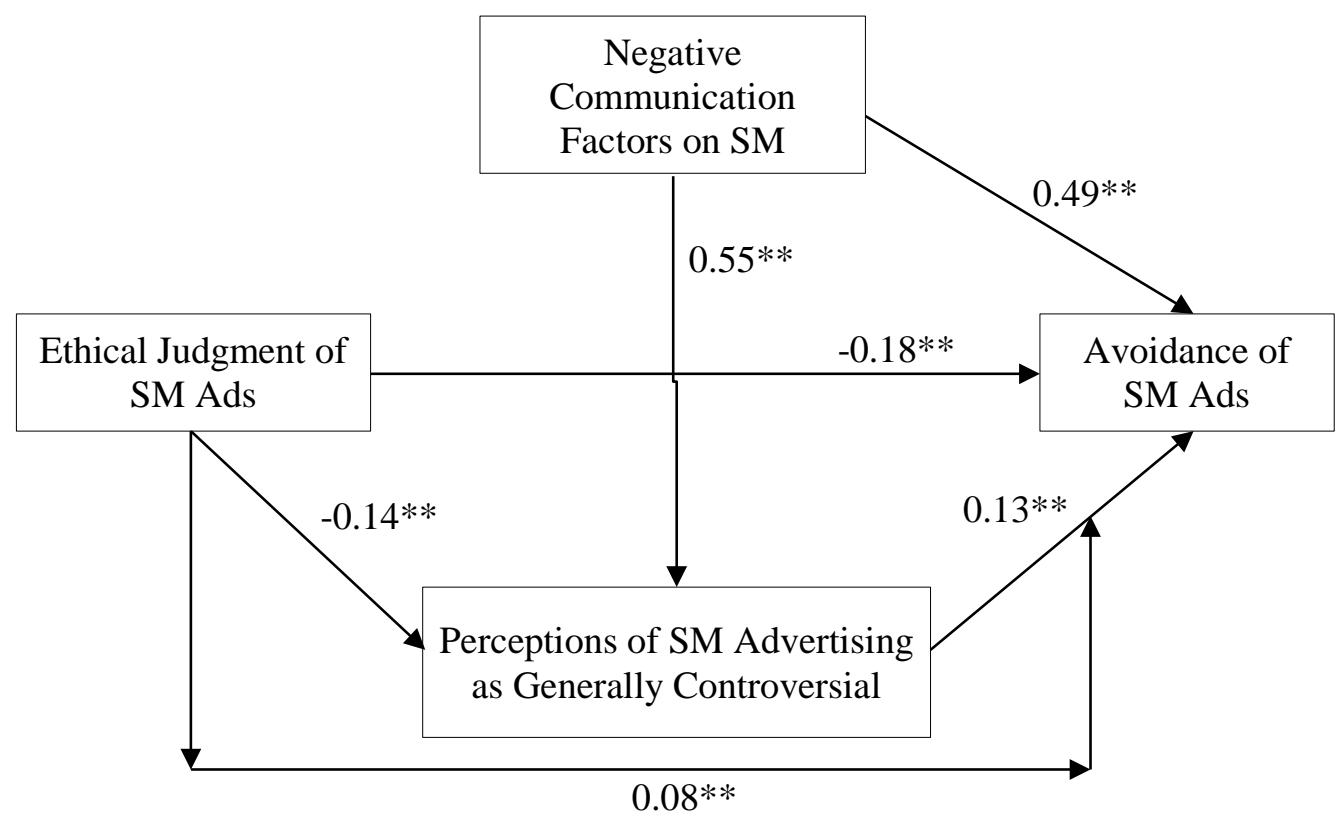

${ }^{* *} \mathrm{p}<0.01,{ }^{*} \mathrm{p}<0.05$, one-tailed regression tests. Numbers are rounded to two decimal points. 


\section{Tables}

Table 1: Sample Statistics

\begin{tabular}{|c|c|c|}
\hline Sample & $\mathbf{n}$ & Percentage \% \\
\hline \multicolumn{3}{|l|}{ Gender } \\
\hline Male & 103 & 38 \\
\hline Female & 170 & 62 \\
\hline \multicolumn{3}{|l|}{ Age } \\
\hline $18-25$ & 22 & 8 \\
\hline $26-35$ & 102 & 38 \\
\hline $36-45$ & 58 & 21 \\
\hline $46-55$ & 69 & 24 \\
\hline $56-65$ & 22 & 8 \\
\hline \multicolumn{3}{|l|}{ Education } \\
\hline GSCEs & 50 & 19 \\
\hline A-level or equivalent & 96 & 35 \\
\hline UG degree & 82 & 30 \\
\hline PG degree & 43 & 16 \\
\hline
\end{tabular}


Table 2: Measures and Reliability Analysis

\begin{tabular}{|c|c|c|c|c|c|c|}
\hline Construct & Scale & $\begin{array}{l}\text { Number } \\
\text { of Items }\end{array}$ & Mean & SD & $\begin{array}{c}\text { Cronbach's } \\
\text { Alpha } \\
\text { (Scale) }\end{array}$ & $\begin{array}{c}\text { Cronbach's } \\
\text { Alpha } \\
\text { (Construct) }\end{array}$ \\
\hline \multirow{2}{*}{$\begin{array}{l}\text { Ethical } \\
\text { Judgement }\end{array}$} & Moral Equity & 2 & 3.52 & 1.20 & 0.76 & \multirow{2}{*}{0.90} \\
\hline & Relativity & 2 & 3.54 & 1.20 & 0.82 & \\
\hline \multirow{3}{*}{$\begin{array}{l}\text { Negative } \\
\text { Communication } \\
\text { Factors on SM }\end{array}$} & $\begin{array}{l}\text { Goal } \\
\text { Impediment }\end{array}$ & 9 & 5.02 & 1.28 & 0.96 & \multirow{3}{*}{0.82} \\
\hline & Ad Clutter & 3 & 4.92 & 1.28 & 0.83 & \\
\hline & $\begin{array}{l}\text { Prior } \\
\text { Negative } \\
\text { Experience }\end{array}$ & 12 & 4.63 & 0.77 & 0.79 & \\
\hline $\begin{array}{l}\text { Perceptions of } \\
\text { SM Advertising } \\
\text { as Generally } \\
\text { Controversial }\end{array}$ & $\begin{array}{l}\text { Perceptions } \\
\text { of SM } \\
\text { Advertising } \\
\text { as Generally } \\
\text { Controversial }\end{array}$ & 6 & 4.59 & 1.08 & 0.87 & 0.87 \\
\hline \multirow{3}{*}{$\begin{array}{l}\text { Ad Avoidance } \\
\text { of SM Ads }\end{array}$} & $\begin{array}{l}\text { Cognitive } \\
\text { Avoidance }\end{array}$ & 7 & 5.43 & 1.30 & 0.95 & \multirow{3}{*}{0.83} \\
\hline & $\begin{array}{l}\text { Affective } \\
\text { Avoidance }\end{array}$ & 8 & 5.65 & 1.23 & 0.96 & \\
\hline & $\begin{array}{l}\text { Behavioural } \\
\text { Avoidance }\end{array}$ & 16 & 4.93 & 1.11 & 0.92 & \\
\hline
\end{tabular}

Scale: 1 strongly disagree to 7 strongly agree. 
Table 3: Discriminant validity

\begin{tabular}{|l|l|l|l|l|}
\hline & $\begin{array}{l}\text { Perception of } \\
\text { SM Ads as } \\
\text { Generally } \\
\text { Controversial }\end{array}$ & $\begin{array}{l}\text { Ethical } \\
\text { Judgment of } \\
\text { SM Ads }\end{array}$ & $\begin{array}{l}\text { Avoidance of } \\
\text { SM Ads }\end{array}$ & $\begin{array}{l}\text { Negative } \\
\text { Communication } \\
\text { Factors on SM }\end{array}$ \\
\hline $\begin{array}{l}\text { Perceptions of SM } \\
\text { Ads as Generally } \\
\text { Controversial }\end{array}$ & $\mathbf{0 . 6 8 8}$ & 0.088209 & 0.305809 & 0.3481 \\
\hline $\begin{array}{l}\text { Ethical Judgment } \\
\text { of SM Ads }\end{array}$ & -.297 & $\mathbf{0 . 8 1 9}$ & 0.101124 & 0.092416 \\
\hline $\begin{array}{l}\text { Avoidance of SM } \\
\text { Ads }\end{array}$ & $.553^{* *}$ & $-.318^{* *}$ & $\mathbf{0 . 6 1 6}$ & 0.446224 \\
\hline $\begin{array}{l}\text { Negative } \\
\text { Communication } \\
\text { Factors on SM }\end{array}$ & $.590^{* *}$ & $-.304^{* *}$ & $.668^{* *}$ & $\mathbf{0 . 5 4 3}$ \\
\hline
\end{tabular}

Note: Correlations are below diagonal, squared correlations are above the diagonal, and AVE estimates are presented on the diagonal. 
Table 4: Parameter estimates and t-values

\begin{tabular}{|l|l|l|}
\hline Hypothesis & Estimate & SE \\
\hline Direct effects & & \\
\hline $\begin{array}{l}\text { H1: Negative Communication Factors on SM -> } \\
\text { Consumer Avoidance of SM Ads }\end{array}$ & $0.49^{* *}$ & 0.07 \\
\hline $\begin{array}{l}\text { H2: Negative Communication Factors on SM -> } \\
\text { Perceptions of SM Advertising as Generally } \\
\text { Controversial }\end{array}$ & $0.55^{* *}$ & 0.07 \\
\hline $\begin{array}{l}\text { H3: Perceptions of SM Advertising as Generally } \\
\text { Controversial -> Consumer Avoidance of SM Ads }\end{array}$ & $0.13^{* *}$ & 0.04 \\
\hline $\begin{array}{l}\text { H4: Ethical Judgment of SM Ads -> Perceptions of SM } \\
\text { Ads as Generally Controversial }\end{array}$ & $-0.14^{*}$ & 0.05 \\
\hline $\begin{array}{l}\text { H5: Ethical Judgment of SM Ads-> Avoidance of SM } \\
\text { Ads }\end{array}$ & $-0.18^{* *}$ & 0.05 \\
\hline $\begin{array}{l}\text { Ads as Generally Controversial > Consumer Avoidance } \\
\text { of SM Ads }\end{array}$ & $0.08^{* *}$ & \\
\hline Interaction effect & & \\
\hline
\end{tabular}

${ }^{* *} \mathrm{p}<0.01,{ }^{*} \mathrm{p}<0.05$, one-tailed regression tests. Numbers are rounded to two decimal points. 